\title{
Profile of bioactive compounds in Nymphaea alba L. leaves growing in Egypt: hepatoprotective, antioxidant and anti-inflammatory activity
}

Riham Omar Bakr ${ }^{1 *}$, Mona Mohamed El-Naa², Soumaya Saad Zaghloul ${ }^{1}$ and Mahmoud Mohamed Omar ${ }^{3,4}$

\begin{abstract}
Background: Nymphaea alba L. represents an interesting field of study. Flowers have antioxidant and hepatoprotective effects, rhizomes constituents showed cytotoxic activity against liver cell carcinoma, while several Nymphaea species have been reported for their hepatoprotective effects. Leaves of N. alba have not been studied before. Therefore, in this study, in-depth characterization of the leaf phytoconstituents as well as its antioxidant and hepatoprotective activities have been performed where $\mathrm{N}$. alba leaf extract was evaluated as a possible therapeutic alternative in hepatic disorders.

Methods: The aqueous ethanolic extract (AEE, 70\%) was investigated for its polyphenolic content identified by high-resolution electrospray ionisation mass spectrometry (HRESI-MS/MS), while the petroleum ether fraction was saponified, and the lipid profile was analysed using gas liquid chromatography (GLC) analysis and compared with reference standards. The hepatoprotective activity of two doses of the extract (100 and $200 \mathrm{mg} / \mathrm{kg}$; P.O.) for 5 days was evaluated against $\mathrm{CCl}_{4}$-induced hepatotoxicity in male Wistar albino rats, in comparison with silymarin. Liver function tests; aspartate aminotransferase (AST), alanine aminotransferase (ALT), alkaline phosphatase (ALP), gamma glutamyl transpeptidase (GGT) and total bilirubin were performed. Oxidative stress parameters; malondialdehyde (MDA), reduced glutathione (GSH), catalase (CAT), superoxide dismutase (SOD), total antioxidant capacity (TAC) as well as inflammatory mediator; tumour necrosis factor (TNF)-a were detected in the liver homogenate. Histopathological examination of the liver and immunohistochemical staining of caspase-3 were performed
\end{abstract}

Results: Fifty-three compounds were tentatively identified for the first time in N.alba leaf extract, where ellagitannins represent the main identified constituents. Nine hydrocarbons, two sterols and eleven fatty acids were identified in the petroleum ether extract where, palmitic acid and linolenic acids represented the major saturated and unsaturated fatty acid respectively. N.alba AEE significantly improved the liver function, oxidative stress parameters as well as TNF-a in addition to the amelioration of histopathological features of the liver and a profound decrease in caspase-3 expression.

Conclusion: These results shed light on the hepatoprotective effect of $\mathrm{N}$. alba that is comparable with that of silymarin. The antioxidant activities of $\mathrm{N}$. alba extract in addition to the inhibition of crucial inflammatory mediator, as TNF-a, might be the possible hepatoprotective mechanisms.

Keywords: Nymphaea alba, Ellagitannins, Palmitic acid, Oxidative stress, Inflammation, Hepatotoxicity

\footnotetext{
* Correspondence: rehambkr@yahoo.com; romar@msa.eun.eg

${ }^{1}$ Pharmacognosy Department, Faculty of Pharmacy, October University for

Modern Sciences and Arts (MSA), Giza, Egypt

Full list of author information is available at the end of the article
} 


\section{Background}

Hepatotoxicity is a prevalent problem worldwide. Carbon tetrachloride $\left(\mathrm{CCl}_{4}\right)$ is a chlorinated hydrocarbon that is commonly used in industries as a solvent and in medicine as a vermifuge. The compound is also found at low levels in ambient air and water [1]. Exposure to $\mathrm{CCl}_{4}$ is known to result in acute hepatotoxicity in humans and experimental animals. It is widely used in scientific research as a model of hepatotoxicity and to evaluate hepatoprotective agents $[2,3] . \mathrm{CCl}_{4}$ is converted by cytochrome P450 2E1 to trichloromethyl free radical $\left(\mathrm{CCl}_{3} \cdot\right)$ and trichloromethylperoxy radical $\left(\mathrm{CCl}_{3} \mathrm{OO} \cdot\right)$. Both radicals initiate lipid peroxidation and protein deterioration with subsequent damage of the cellular membrane and leakage of intracellular enzymes into the serum. These processes eventually lead to inactivation of the calcium pump with calcium influx and subsequent liver cell death. Moreover, lipid peroxidation and damage of hepatocyte membranes initiated by $\mathrm{CCl}_{4}$ was reported to be associated with the release of inflammatory mediators such as tumour necrosis factor (TNF)- $\alpha$ from activated hepatic macrophages, which potentiate $\mathrm{CCl}_{4}$-induced hepatic injury [3, 4].

Nymphaea alba L. (N. alba), known as the European water lily, White Lotus, or Nenuphar, is an aquatic flowering plant of the family Nymphaeaceae. $N$. alba was widely used in Indian folk medicinal products as an antiseptic, an astringent, radical scavenger, in burning and in insomnia while rhizomes are applied externally as a rubefacient [5]. Previously published studies reported the antioxidant, anti-inflammatory as well as hepatoprotective effect of $N$. alba flowers [6-8]. These effects may result from the phenolic constituents, including ellagic and gallic acid and their methyl and ethyl esters and flavonoids as aglycones of quercetin, kaempferol, isokaempferide, apigenin and their glycosides previously identified in the flowers $[9,10]$. A recent study on the rhizomes revealed the presence of hydrolysable tannins, glycosylated phenolic acids and flavonoids. The methyl and ethyl gallate as well as pentagalloyl glucose, the main constituents identified, showed powerful cytotoxic activity against liver cell carcinoma [11]. Leaves of the white flowered water lily have been evaluated for their cytotoxic, antiproliferative and anxiolytic activities [12-14].

The broad range of traditional uses along with the previous reports concerning the hepatoprotective effect of $N$. alba flowers [7] as well as other Nymphaea species [15], and the absence of any reports about the phytochemical profile of $N$. alba leaf, aroused our interest in $N$. alba as a source of bioactive compounds. This study represents the first detailed chemical investigation of $N$. alba leaf that demonstrates the presence of a variety of free and conjugated forms of ellagic acid and ellagitannins tentatively identified by high-resolution electrospray ionisation mass spectrometry (HRESI-MS/MS) in the aqueous ethanolic extract.
Hepatoprotective, antioxidant and anti-inflammatory activity of the $N$. alba leaf extract against $\mathrm{CCl}_{4}$ - induced hepatotoxicity have also been studied and showed promising results.

\section{Methods \\ Plant material}

Leaves of $N$. alba L. were collected from El Orman Gardens, Giza, Egypt, in November, 2013 during the flowering stage. Authentication of the plant was performed by Dr. Therese Labib Youssef (consultant in plant taxonomy, Ministry of Agriculture). A voucher specimen (RS006) is deposited at the herbarium of the Pharmacognosy Department, Faculty of Pharmacy, October University for Modern Science and Arts, Egypt.

\section{Extraction}

The powdered air-dried leaves of $N$. alba (300 g) were exhaustively extracted with aqueous ethanol $(70 \% \mathrm{v} / \mathrm{v})$ under reflux. After filtration, the aqueous ethanolic extract (AEE) was evaporated to dryness in vacuum at $40{ }^{\circ} \mathrm{C}$ to yield $33 \mathrm{~g}$.

\section{Liquid chromatography coupled with High-resolution} electrospray ionisation mass spectrometry (LC-HRESI-MS/MS) LC-HRESI-MS/MS was performed on a Bruker MicroTOF-Q Daltonics (API) Time-of-Flight mass spectrometer (Bremen, Germany), coupled to a 1200 series HPLC system (Agilent Technologies, Waldbronn, Germany), equipped with a high performance autosampler, binary pump, and PDA detector G 1314 C (SL). Chromatographic separation was performed on a Superspher 100 RP-18 $(75 \times 4$ mm i.d.; $4 \mu \mathrm{m})$ column (Merck, Darmstadt, Germany).

\section{Identification of Phenolic Compounds of AEE of N. alba by LC-HRESI-MS/MS}

The method was performed according to Hassaan et al. [16]. Injection volume was $10 \mu \mathrm{L}$. The solvents were: (A) $2 \%$ acetic acid (pH 2.6) and (B) 80\% methanol, 2\% acetic acid, and $\mathrm{pH}$ 2.6. The gradient elution was from 5 to $50 \%$ $\mathrm{B}$ at $30{ }^{\circ} \mathrm{C}$ at a flow rate of $100 \mu \mathrm{L} / \mathrm{min}$. The ionization technique was an ion spray (pneumatically assisted electrospray). Spectra were recorded in positive and negative ion modes between $\mathrm{m} / z 120$ and 1,500 with capillary voltage, $4000 \mathrm{~V}$ and heated dry nitrogen gas (temperature, $200{ }^{\circ} \mathrm{C}$ ) and flow rate $10 \mathrm{~L} / \mathrm{min}$. The gas flow to the nebulizer was set at pressure 1.6 bar. For collision-induced dissociation (CID) MS/MS measurements, the voltage over the collision cell varied from 20 to $70 \mathrm{eV}$. Argon was used as the collision gas. Data analysis software was used for data interpretation. Sodium formate was used for calibration at the end of the LC/MS run. Interpretation for ESI-MS was performed by Xcalibur 2.2 SP1 software from Thermo Scientific (Berlin, Germany). 


\section{Gas Liquid Chromatography (GLC) of Unsaponifiable Matter (USM) and Fatty Acid Methyl Ester (FAME)}

Powdered air-dried leaves (100 g) were exhaustively extracted with petroleum ether $\left(60-80{ }^{\circ} \mathrm{C}\right)$. The petroleum ether extract was filtered and evaporated under reduced pressure. The petroleum ether extract $(1 \mathrm{~g})$ was saponified by refluxing with ethanolic $\mathrm{KOH}(20 \%)$ at $60{ }^{\circ} \mathrm{C}$ for $2 \mathrm{~h}$ and then exhaustively extracted with ether. The combined ethereal extracts were washed, dehydrated over anhydrous sodium sulphate, evaporated to dryness and then analysed as unsaponifiable matter (USM) for the hydrocarbon and sterol contents. The saponified extract was acidified with $\mathrm{HCl}(5 \mathrm{~N})$ and then extracted several times with ether. The combined ethereal extracts were evaporated to dryness, esterified into fatty acid methyl esters (FAMEs) by reflux with $\mathrm{MeOH}: \mathrm{H}_{2} \mathrm{SO}_{4}$ (50:3) and extracted with ether [17].

The ether extracts of the USM and FAME fractions were analysed by GLC against the available authentic standards. Identification of hydrocarbons, sterols, and fatty acid methyl esters was carried out by comparing retention times of the peaks with those of the available authentic standards. FAMEs were analysed on a 70\% Thermo Scientific Trace TR-FAME gas chromatographic (GC) capillary column packed with 70\% Cyanopropyl Polysilphenylenesiloxane, $30 \mathrm{~m} \times 0.25 \mathrm{~mm}$ id. The injector and detector temperatures were set at 250 and $300{ }^{\circ} \mathrm{C}$, respectively. The temperature was increased $70^{\circ} \mathrm{C}$ to $190{ }^{\circ} \mathrm{C}$ at a rate of $8^{\circ}$ $\mathrm{C} / \mathrm{min}$. Nitrogen was used as carrier gas $(30 \mathrm{ml} / \mathrm{min})$.

USM was analysed on a Capillary HP6890 series, $1.5 \mathrm{~m} \times 4 \mathrm{~mm}$ i.d. The injector and detector temperatures were set at 250 and $300{ }^{\circ} \mathrm{C}$, respectively. The temperature was increased from 70 to $270{ }^{\circ} \mathrm{C}$, at a rate of $10{ }^{\circ} \mathrm{C} / \mathrm{min}$. Nitrogen was used as the carrier gas $(30 \mathrm{~mL} / \mathrm{min})$.

\section{1, 1-Diphenyl-2-picrylhydrazyl (DPPH) radical scavenging activity}

A weighed amount of AEE was dissolved in methanol $(100 \mu \mathrm{g} / \mathrm{mL})$, screened for its free radical scavenging activity using the stable free radical DPPH, and then measured spectrophotometrically. The absorbance was measured at $517 \mathrm{~nm}$ and carried out in triplicate [18]. Radical scavenging activity was calculated by the following formula: DPPH scavenging effect $(\%)=[(\mathrm{A} 0-\mathrm{A} 1) / \mathrm{A} 0) \times 100]$, where $\mathrm{A} 0$ was the absorbance of the control reaction, and $\mathrm{A} 1$ was the absorbance of the sample [19]. The concentration of sample required to scavenge $50 \%$ of the DPPH was calculated from a graph plotted for the \% inhibition against the concentration in $\mu \mathrm{g} / \mathrm{mL}$. Ascorbic acid was used as standard.

\section{Hepatoprotective activity}

\section{Experimental animals}

Eight-week-old male Wistar albino rats (200-220 g) were purchased from the National Institute of Ophthalmology, Egypt. The animals were kept in the animal house, October
University for Modern Sciences and Arts (MSA), Egypt. All animals were kept in a pathogen-free facilities under standard laboratory conditions (temperature $25 \pm 2{ }^{\circ} \mathrm{C}$ and $12 \mathrm{~h}$ light/12 h dark cycle) with free access to food and water. The animals were housed in groups of four in plastic cages with sawdust bedding. Experimental work was carried out in laboratories at MSA University, Egypt. Procedures involving animals and their care were in conformity with the institutional guidelines (Approval number of ethics committee, MSA University, EC 10 PG10/2011) and in compliance with national and international laws on the care and use of laboratory animals.

\section{Experimental design}

Two different doses of $N$. alba (100 and $200 \mathrm{mg} / \mathrm{kg}$ ) were tested for their hepatoprotective effect against $\mathrm{CCl}_{4}$-induced hepatotoxicity. Doses and route of administration selection were according to previously published studies $[12,13]$. Hepatotoxicity was induced by injection of a single intraperitoneal (I.P.) dose of $\mathrm{CCl}_{4}(0.5 \mathrm{ml} / \mathrm{kg})$ [20].

A total of 40 rats were randomly divided into five groups $(n=8)$. Group I (Control): received vehicles. Group II $\left(\mathrm{CCl}_{4}\right)$ : received $\mathrm{CCl}_{4}(0.5 \mathrm{ml} / \mathrm{kg}$; I.P. $)$ once. Group III ( $N$. alba low dose): received $\mathrm{CCl}_{4}(0.5 \mathrm{ml} / \mathrm{kg}$; I.P. $)+N$. alba extract (100 mg/kg; P.O.) $24 \mathrm{~h}$ after $\mathrm{CCl}_{4}$ for 5 days. Group IV (N. alba high dose): received $\mathrm{CCl}_{4}$ $(0.5 \mathrm{ml} / \mathrm{kg}$; I.P. $)+N$. alba $(200 \mathrm{mg} / \mathrm{kg}$; P.O. $) 24 \mathrm{~h}$ after $\mathrm{CCl}_{4}$ for 5 days. Group V (Silymarin): received $\mathrm{CCl}_{4}$ $(0.5 \mathrm{ml} / \mathrm{kg}$; I.P. $)+$ silymarin $(100 \mathrm{mg} / \mathrm{kg}$; P.O. $) 24 \mathrm{~h}$ after $\mathrm{CCl}_{4}$ for 5 days. Treatments were given at 10 a.m. Twenty-four hours after the last dose of treatments, blood samples were collected from the retro-orbital plexus. Serum was separated by centrifugation and stored at $-80^{\circ}$ C. Rats were sacrificed; livers were excised, rinsed in icecold saline and blotted dry. Slices of liver tissue were fixed in $10 \%$ neutral formalin for histopathological examination and immunostaining of caspase-3. The rest of the liver tissue was weighed and homogenized in phosphate buffer saline to prepare $10 \%$ homogenate and stored at $-80{ }^{\circ} \mathrm{C}$.

\section{Assessment of biochemical markers of hepatic injury}

Biochemical parameters reflecting liver functions such as serum aspartate aminotransferase (AST), alanine aminotransferase (ALT), alkaline phosphatase (ALP), gamma glutamyl transpeptidase (GGT) and total bilirubin were estimated using commercially available kits, according to the manufacturer instructions (Spectrum, Egypt).

\section{Assessment of oxidative stress in the liver}

Liver malondialdehyde (MDA) and reduced glutathione (GSH) contents, catalase (CAT) and superoxide dismutase (SOD) activities and total antioxidant capacity (TAC) were assessed spectrophotometrically using commercial kits supplied by Bio-diagnostic (Bio-diagnostic, Egypt). 
Estimation of inflammatory cytokine, TNF- $a$

TNF- $\alpha$ content was measured in liver homogenate using an ELISA kit (BioLegend ELISA MAX ${ }^{\mathrm{m}}$ Deluxe kit; BioLegend, San Diego, CA, USA). The assay was performed according to the manufacturer's protocol.

\section{Histopathological examination of the liver}

Liver specimens in $10 \%$ neutral formalin were embedded in paraffin and cut into $4 \mu \mathrm{m}$ thick sections. Sections were stained with haematoxylin and eosin (H\&E) and examined under a light microscope for histological changes.

\section{Immunohistochemical staining for caspase-3 in liver}

Caspase-3 expression in the liver was detected by immunostaining of sections prepared from formalin-fixed, paraffinembedded livers using caspase-3 detection kits according to the manufacturer instructions. The intensity of caspase-3 immunostaining was assessed as follows: 0 - none, $1-$ mild, 2 - moderate and 3 - strong. The Immunohistochemical histological score (H-score) was calculated by multiplying the intensity by the percentage of caspase- 3 positive cells, creating a range of possible scores of 0-300 [21].

\section{Statistical analysis}

Data from animal work are expressed as the mean \pm standard error of the mean (SEM). Comparisons between different groups were carried out by one-way analysis of variance (ANOVA) followed by the Tukey-Kramer test. The level of significance was set at $p<0.05$. Graphpad software instat (version 2) was used to carry out statistical analysis.

\section{Results}

\section{Phytochemical investigation}

\section{HRESI-MS/MS analysis of N. alba AEE}

The chemical constituents in $N$. alba AEE were identified and characterized in both negative and positive ESI modes. The retention times and fragmentation patterns of the identified compounds are listed in Table 1. Compounds were tentatively identified based on matching their masses and fragmentation pattern with the literature information and ChemSpider. MS fragmentation interpretation is not discussed except when of special interest.

Table 1 outlines 53 compounds, among them 42 hydrolysable tannins, three simple phenolic acids, and eight flavonoids were detected.

\section{Estimation of USM and FAME}

Nine hydrocarbons, two sterols and eleven fatty acids were identified in $N$. alba AEE. The percentage content of individual hydrocarbons and fatty acids are summarized in Tables 2 and 3. The percentage of identified hydrocarbons was estimated as $94.9 \%$ while the sterol content represented $5.03 \%$. $n$-Tetracosane was determined as the major hydrocarbon (59.6\%), n-tetratriacontane was detected as the second most abundant hydrocarbon (18.96\%) while $\beta$ sitosterol was of significant percentage (3.5\%). By comparison with the FAME standards, the percentage of the saturated fatty acid represents $49.3 \%$ where the major saturated fatty acid was palmitic acid (40.8\%) while the major unsaturated fatty acids were linolenic acid (24.5\%), linoleic acid (16.8\%) and palmitoleic acid (8.5\%).

\section{1, 1-Diphenyl-2-picrylhydrazyl (DPPH) radical scavenging activity}

AEE showed strong DPPH scavenging activity as indicated by low $\mathrm{IC}_{50}(5.2 \pm 0.3 \mu \mathrm{g} / \mathrm{mL})$ and $\mathrm{LC}_{90}(9.1 \pm 0.27 \mu \mathrm{g} / \mathrm{mL})$ compared with ascorbic acid $(12 \pm 3.5 \mu \mathrm{g} / \mathrm{mL})$.

\section{Hepatoprotective activity}

Effect of N. alba on liver function parameters

Serum level of liver functions parameters; ALT, AST, GGT, ALP and total bilirubin were significantly increased in $\mathrm{CCl}_{4}$-intoxicated rats compared with normal level $(P<$ 0.05; Table 4). Treatment with N. alba (100 and $200 \mathrm{mg} /$ $\mathrm{kg}$ ) resulted in significant decrease of ALT, AST, GGT, ALP and total bilirubin compared with $\mathrm{CCl}_{4}$-intoxicated rats in a dose dependant manner $(P<0.05$; Table 4$)$. Similarly, silymarin significantly improved the liver function parameters compared with $\mathrm{CCl}_{4}$ group $(P<0.05$; Table 4$)$.

\section{Effect of N. alba on oxidant status of the liver}

Injection of $\mathrm{CCl}_{4}$ resulted in depletion of hepatic $\mathrm{GSH}$ content (59.7\%), decrease in the activities of SOD and CAT (59.9 and 44.9\%, respectively) and decline in TAC of the liver (65.7\%) $(P<0.05$; Figs. 1, 2, 3 and 4, respectively) compared with control group. Also, $\mathrm{CCl}_{4}$ significantly increased the liver lipid peroxidation product, MDA (249.1\%) $(P<0.05$; Fig. 5) compared with control group.

Treatment of $\mathrm{CCl}_{4}$-intoxicated rats with $N$. alba (100 and $200 \mathrm{mg} / \mathrm{kg}$ ) significantly increased the liver content of GSH (55.1 and 143.4\%, respectively; $P<0.05$; Fig. 1 ) compared with the $\mathrm{CCl}_{4}$ group. N. alba (100 and $200 \mathrm{mg} / \mathrm{kg}$ ) significantly enhanced the enzymatic activities of both SOD (79.1 and 111.1\%, respectively) and CAT (49.2 and $75.5 \%$, respectively) $(P<0.05$; Figs. 2 and 3 , respectively) compared with the $\mathrm{CCl}_{4}$ group. Furthermore, TAC of the liver increased significantly (84.1 and $173.5 \%)$ by treatment with the $N$. alba (100 and $200 \mathrm{mg} / \mathrm{kg}$, respectively) $(P<0.05$; Fig. 4). On the other hand, treatment with $N$. alba (100 and $200 \mathrm{mg} / \mathrm{kg}$ ) significantly decreased liver MDA content (38.2 and 67.6\%), respectively, compared with the $\mathrm{CCl}_{4}$ group $(P<0.05$; Fig. 5$)$.

Silymarin significantly increased the liver GSH content and TAC (151.7 and 97.3\%, respectively) compared with the $\mathrm{CCl}_{4}$ group $(P<0.05$; Figs. 1 and 4 , respectively). The activities of SOD and CAT improved significantly (71 and $73.8 \%$, respectively) by treatment with silymarin compared with the $\mathrm{CCl}_{4}$ group $(P<0.05$; Figs. 2 and 3 , respectively). 
Table 1 Peak assignments and tentative identification of the major constituents in N. alba AEE by HRESI-MS/MS in the positive and negative modes

\begin{tabular}{|c|c|c|c|c|c|c|}
\hline $\begin{array}{l}\text { Peak } \\
\text { Number }\end{array}$ & $\begin{array}{l}\text { Tentatively Identified } \\
\text { Compound }\end{array}$ & $\begin{array}{l}\mathrm{tR}^{\mathrm{b}} \\
(\min .)\end{array}$ & $\begin{array}{l}{[\mathrm{M}-\mathrm{H}]^{-} \mathrm{m} /} \\
\mathrm{z}^{\mathrm{d}}\end{array}$ & $\begin{array}{l}\text { Negative lonization } \\
\text { MS/MS }^{\mathrm{C}}\end{array}$ & $\begin{array}{l}{[\mathrm{M}+\mathrm{H}]^{+} \mathrm{m} /} \\
\mathrm{z}^{\mathrm{d}}\end{array}$ & $\begin{array}{l}\text { Positive lonization } \\
\text { MS/MS }\end{array}$ \\
\hline 1 & HHDPe -hexoside & 1.85 & 481.06 & 301.14463 .2275 .18 & 483.08 & 465.14437 .07309 .07263 \\
\hline 2 & Epicatechin derivative & 2.94 & 427.09 & $\begin{array}{l}265.15307 .14367 .23289 .19 \\
247.1221 .15\end{array}$ & & \\
\hline 3 & Ellagitannin derivative & 3.59 & 817.07 & $\begin{array}{l}773481301.11481 .24 \\
275.19247 .23\end{array}$ & 819.09 & $\begin{array}{l}\text { 801.2 } 481.13463 .05337 .14 \\
319.14303 .12\end{array}$ \\
\hline 4 & HHDP-galloyl-ellagic acid & 4.12 & 773.09 & 301.17729471 .27275 .24247 & & \\
\hline 5 & Ellagic acid & 4.44 & 301.15 & 257.22229 .10185 .16 & 303.1 & $\begin{array}{l}275.03257 .1247 .04229 .13 \\
165.02\end{array}$ \\
\hline 6 & Isorhamnetin derivative & 5.38 & 386.96 & $\begin{array}{l}315343.21271 .16255 .16 \\
189.02161 .06\end{array}$ & & \\
\hline 7 & Quercetin 3-O-acetyl hexoside & 12.73 & 505.07 & $\begin{array}{l}\mathbf{4 5 9 . 1 9} 403.18487 .14301 .12 \\
275.17231 .25247 .09169 .12\end{array}$ & 507.09 & $\begin{array}{l}\mathbf{4 8 9 . 1 4} 447.14405 .14387 .03 \\
303.18205 .14187 .17\end{array}$ \\
\hline 8 & Ellagic rhamnosyl hexoside & 13.27 & 609.17 & $\begin{array}{l}403.17563 .18447 .3429 .2359 .2 \\
291.22301 .13275 .28247 .19\end{array}$ & 611.18 & $\begin{array}{l}\mathbf{5 9 3 . 3 0} 551.30533 .27449 .30 \\
389.21343 .21303 .22\end{array}$ \\
\hline 9 & $\begin{array}{l}\text { Lagerstannin A } \\
\text { (Bis-HHDP-gluconic acid) }\end{array}$ & 13.40 & 799.06 & 497.16301 .21755 .24453 .26 & 801.08 & $\begin{array}{l}463.15765 .11783 .17481 .15 \\
337.12303 .15277 .10247 .15\end{array}$ \\
\hline 10 & Brevifolin & 13.5 & 247.02 & 203.11 bp 175.13 & 249.6 & $\begin{array}{l}207.05232 .12221 .12187 .08 \\
159.04131 .04\end{array}$ \\
\hline 11 & Phyllanthusiin U & 13.72 & 924.11 & $\begin{array}{l}301.01622 .2604 .24905 .22 \\
451.19\end{array}$ & 926.13 & $\begin{array}{l}908.2303 .12277 .15703 .25 \\
606.26\end{array}$ \\
\hline 12 & Valoneic acid dilactone dimer & 13.81 & 939.02 & $\mathbf{4 6 9 . 2 4} 425.21300 .2$ & 941.02 & $\begin{array}{l}453.15922 .27621 .2470 .99 \\
407.19\end{array}$ \\
\hline 13 & $\begin{array}{l}\text { 3,4,8,9,10-Pentahydroxydibenzo } \\
{[\mathrm{b}, \mathrm{d}] \text { pyran-6-one }}\end{array}$ & 14.13 & 275.02 & $\begin{array}{l}245.05257 .08231 .1229 .2 \\
203.08187 .18\end{array}$ & 277.03 & 235.23221 .17183 .17 \\
\hline 14 & Luteolin & 14.34 & 285.04 & $\begin{array}{l}\mathbf{2 5 7 . 1 6} 241.13229 .2213 .23 \\
185.2167 .24\end{array}$ & & \\
\hline 15 & Ellagitannin derivative & 14.45 & 931.11 & 301.14783 .2 & 933.03 & 873.05915 \\
\hline 16 & Methyl gallate & 14.56 & 183.03 & 168.13124 .03169 .09 & 185.33 & 167.07153 .03104 .96129 .07 \\
\hline 17 & Ellagic acid hexoside & 15.54 & 463.05 & $\begin{array}{l}301.2419 .2417 .16331 .7274 .96 \\
251.07247 .2\end{array}$ & 465.05 & 303.09447 .13 \\
\hline 18 & $\begin{array}{l}\text { Catechin or epicatechin } \\
\text { derivative }\end{array}$ & 15.83 & 621.07 & $\begin{array}{l}\mathbf{5 7 5 . 4 6} 439.15289 .19 \\
245.10217 .14\end{array}$ & & \\
\hline 19 & Orientin & 16.3 & 447.02 & $\begin{array}{l}403.16233 .03427 .03359 .17 \\
277.12357 .18329 .16327 .18 \\
315.23 \quad 301.19287 .17189 .05\end{array}$ & & \\
\hline 20 & Ellagitannin derivative & 16.63 & 755.07 & $\begin{array}{l}711.24453 .19301 .21435 .21 \\
409.36275247 .23\end{array}$ & & \\
\hline 21 & Phyllanthusiin E & 17.04 & 291.04 & 247.11203 .18 & 293.03 & 247.11275 .06 \\
\hline 22 & Ellagitannin derivative & 17.17 & 1153.09 & 799.17755 .21453 .16409 .24 & & \\
\hline 23 & Phyllanthusiin B isomer & 18.05 & 969.09 & $\begin{array}{l}\mathbf{6 3 1 . 2 5} 667.22451 .15 \\
331.27291 .07\end{array}$ & & \\
\hline 24 & Castalin derivative & 18.77 & 967.07 & 631.14451 .2571 .19 & 969.08 & $\begin{array}{l}950.82499 .10579 .02481 .16 \\
453.10355 .1337 .17\end{array}$ \\
\hline 25 & HHDP-gluconic acid & 19.21 & 497.06 & $\begin{array}{l}\mathbf{4 6 3 . 2 0} 453.24301 .07 \\
291.18275 .18257 .25247 .23\end{array}$ & & \\
\hline 26 & Ellagic acid-galloyl hexoside & 20.85 & 613.05 & 451.13425 .26569 .22509 .16 & & \\
\hline 27 & Phyllanthusiin B & 21.17 & 969.09 & $\begin{array}{l}\mathbf{6 3 3 . 2 6} 923.18951 .26667 .26 \\
\text { ch301.24 } 451.30275 .18\end{array}$ & 971.1 & $\begin{array}{l}953.16651 .14633 .17615 .15 \\
481.21453 .18303 .15277 .17\end{array}$ \\
\hline
\end{tabular}


Table 1 Peak assignments and tentative identification of the major constituents in N. alba AEE by HRESI-MS/MS in the positive and negative modes (Continued)

\begin{tabular}{|c|c|c|c|c|c|c|}
\hline 28 & Vescalagin or castalagin & 21.28 & 933.06 & $\begin{array}{l}\mathbf{6 1 3 . 2 0} 301.15631 .2 \\
273.14915 .21\end{array}$ & 935.07 & $\begin{array}{l}916.31615 .34481 .12453 .13 \\
303.19277 .18\end{array}$ \\
\hline 29 & Apigenin & 24.66 & 269.03 & 223.01179 .07 & & \\
\hline 30 & Phyllanthusiin C & 24.91 & 925.10 & $\begin{array}{l}605.29301 .08623 .23905 .15 \\
633.08453 .09291 .18273 .06\end{array}$ & 927.11 & $\begin{array}{l}909.26607 .23589 .14571 .16 \\
419.23321 .19303 .1277 .11\end{array}$ \\
\hline 31 & $\begin{array}{l}\text { Corilagin (Galloyl HHDP } \\
\text { hexoside) }\end{array}$ & 25.14 & 633.07 & $\begin{array}{l}\mathbf{3 0 1 . 1 4} 589.22481 .29 \\
275.27257 .15\end{array}$ & 635.08 & $\begin{array}{l}\mathbf{4 4 3 . 1 1} 617.23573 .16 \\
355.11254 .15191 .12\end{array}$ \\
\hline 32 & $\begin{array}{l}\text { Pedunculagin } \\
\text { (Bis HHDP-hexoside) }\end{array}$ & 25.77 & 783.07 & $\mathbf{4 8 1 . 1 7} 737.33301 .11451 .11$ & 785.08 & 767.15 \\
\hline 33 & Castalin & 26.17 & 631.06 & 301.20299 .12451 .18271 .05 & 633.07 & 615.12 \\
\hline 34 & Phyllanthusiin $C$ derivative & 27.24 & 1217.12 & 925.56 & & \\
\hline 35 & $\begin{array}{l}\text { Lagerstannin C } \\
\text { (Galloyl-HHDP-gluconic acid }\end{array}$ & 27.33 & 649.1 & $\begin{array}{l}603.26605 .27631 .23469 .18 \\
441.17451 .26301 .14247 .19\end{array}$ & 651.08 & 633.13481 .19337 .11 \\
\hline 36 & Catechin or epicatechin & 28.29 & 289.12 & 245.09217 .18 & 291.42 & $\begin{array}{l}247.1272 .03235 .09 \\
219.07191 .07\end{array}$ \\
\hline 37 & $\begin{array}{l}\text { Lagerstannin B } \\
\text { (flavogalloyl } \\
\text { HHDP-gluconic acid) }\end{array}$ & 29.82 & 949.11 & $\begin{array}{l}\mathbf{6 4 7 . 2 5} 905.25629 .24477 .24 \\
333.21301 .15275 .2\end{array}$ & & \\
\hline 38 & $\begin{array}{l}\text { Granatin B(Galloyl-HHDP- } \\
\text { DHHDP-hex) }\end{array}$ & 30.97 & 951.08 & $\begin{array}{l}605.26649 .21301 .15631 .23 \\
907.21952 .19497 .23\end{array}$ & 953.08 & $\begin{array}{l}\mathbf{2 7 7 . 1 0} 935.15633 .24 \\
615.12321 .11303 .11\end{array}$ \\
\hline 39 & $\begin{array}{l}\text { Dehydrated tergallic } \\
\text { C-glucoside }\end{array}$ & 31.4 & 613.05 & $\begin{array}{l}299.07301 .27569 .27 \\
595.15227 .15\end{array}$ & 615.06 & 453.14387 .09313 .15 \\
\hline 40 & Cinnamic acid derv. & 31.5 & 329.09 & 197.10239 .1169 .07 & 331.13 & $\begin{array}{l}299.09313 .19272 .12 \\
236.09151 .04\end{array}$ \\
\hline 41 & Phyllanthusin B derivative & 32.18 & 981.59 & 969.23933 .23613 .24481 .26 & & \\
\hline 42 & Valoneic acid dilactone & 32.47 & 469 & 425.15301 .09 & & \\
\hline 43 & Gallic acid derivative & 32.61 & 198.62 & 169.06153 .14125 .21117 .06 & & \\
\hline 44 & Ellagitannin derivative & 33.31 & 907.08 & $\begin{array}{l}605.19863 .09587 . .23561 .23 \\
301.14275 .11\end{array}$ & 909.09 & $\begin{array}{l}890.22703 .08589 .21 \\
321.19303 .05277 .09\end{array}$ \\
\hline 45 & Digalloyl ellagic acid & 33.62 & 605.62 & $\begin{array}{l}\mathbf{5 6 1 . 2 5} 247.18291 .12203 .18 \\
453.24435 .12229 .08\end{array}$ & 607 & $\begin{array}{l}315.05589 .27565 .23 \\
549.25505 .27\end{array}$ \\
\hline 46 & Castalgin derivative & 34.51 & 965.09 & 631.22301 .03 & 967.10 & $\begin{array}{l}\mathbf{6 4 7 . 2 5} 949.1906 .2629 .26 \\
495.16445 .26303 .1827 .10\end{array}$ \\
\hline 47 & Chebulagic acid & 34.79 & 953.18 & $\begin{array}{l}\text { 935.32, 907.22 649.28 } 605.1 \\
631.28301 .22291 .24\end{array}$ & 955.19 & $\begin{array}{l}937.20633 .17481 .26463 .28 \\
319.11301 .1627 .19\end{array}$ \\
\hline 48 & Ellagic acid pentoside & 38.56 & 433.04 & $\begin{array}{l}291.15 \text { bp } 405.17301 .18 \\
275.23247229\end{array}$ & 435.15 & $\begin{array}{l}417.19 \text { bp } 407.25399 .14376 .35 \\
343.11325 .11299 .19181 .19\end{array}$ \\
\hline 49 & Ellagic acid rhamnosyl & 39.07 & 447.02 & $\begin{array}{l}359.17403 .2385 .11315 .25 \\
301.13275 .18\end{array}$ & 448.98 & 413.09405 .24331 .08277 .1 \\
\hline 50 & Geraniin & 40.40 & 951.07 & 933.10613 .20301 .13631 .15 & & \\
\hline 51 & Vescalagin derivative & 40.8 & 965.09 & 613.2933 .19301 .09 & 967.10 & 935.17647 .22277 .12 \\
\hline 52 & Galloyl ellagic acid & 41.83 & 453.04 & $\begin{array}{l}301.13438 .34291 .12 \\
247.11169 .13273 .27\end{array}$ & 455.08 & 437.13394 .98 \\
\hline 53 & Gallic acid & 62.11 & 169.01 & 125.11 & & \\
\hline
\end{tabular}

Boldface digits reflects the base peak ( $100 \%$ abundance)

Fragment ions are listed in order of relative abundances

${ }^{\mathrm{a}}$ High resolution liquid chromatography coupled with electrospray ionisation mass /mass spectometry

${ }^{\mathrm{b}}$ Retention time

'Mass/Mass spectrometry

${ }^{d}$ Mass to charge ratio

${ }^{\mathrm{e}}$ Hexahydroxydiphenic acid 
Table 2 Unsaponifiable content in N. alba

\begin{tabular}{lc}
\hline Compound & Percent \\
\hline n-tetradecane, C14 & 0.97 \\
n-pentadecane, C15 & 0.84 \\
$n$ - hexadecane, C16 & 1.11 \\
n-octadecane, C18 & 9.69 \\
$n$-nonadecane, C19 & 1.13 \\
n-tetracosane, C24 & 59.59 \\
n-octacosane, C28 & 2.67 \\
n-tetratriacontane, C30 & 18.96 \\
Total hydrocarbons & 94.96 \\
stigmasterol & 1.68 \\
$\beta$-sitosterol & 3.35 \\
Total sterols & 5.03 \\
\% Unidentified & 0.006 \\
\hline
\end{tabular}

The hepatic content of MDA decreased significantly (51.8.7\%) compared with the $\mathrm{CCl}_{4}$ group $(P<0.05$; Fig. 5).

\section{Effect of N. alba on hepatic content of TNF-a}

Hepatic content of TNF- $\alpha$ was significantly increased in $\mathrm{CCl}_{4}$ group compared with control rats. Treatment with $N$. alba (100 and $200 \mathrm{mg} / \mathrm{kg}$ ) resulted in significant decrease of TNF- $\alpha$ in a dose dependant manner (Fig. 6). Silymarin significantly improved the hepatic content of TNF- $\alpha$ compared with $\mathrm{CCl}_{4}$ control group (Fig. 6).

Table 3 Fatty acid composition (\%) of N. alba

\begin{tabular}{|c|c|}
\hline Compound & Percent \\
\hline Octanoic (Caprylic) acid, C8:0 & 1.22 \\
\hline Decanoic (Capric) acid, C10:0 & 1.67 \\
\hline Tetradecanoic (Myristic) acid, C14:0 & 1.64 \\
\hline Hexadecanoic (Palmitic) acid, C16:0 & 40.84 \\
\hline Octadecanoic (Stearic) acid, C18 & 1.43 \\
\hline Eicosanoic (Archidic) acid, C2O & 2.51 \\
\hline$\sum S F A^{a}$ & 49.31 \\
\hline cis-9-Hexadecanoic(Palmitoleic) acid, C16:1 7 & 8.41 \\
\hline cis-9-Octadecanoic (Oleic) acid, C18:1w9 & 1.04 \\
\hline$\sum M U F A^{b}$ & 9.45 \\
\hline cis,cis-9,12-Octadecadienoic (Linolenic) acid, C18:3, w6 & 24.45 \\
\hline All cis-6,12,15-Octadecotrionic (Linoleic) acid, C18:2 $\omega 6$ & 16.78 \\
\hline$\sum$ PUFAs $^{c}$ & 41.23 \\
\hline Total unsaturation & 50.68 \\
\hline
\end{tabular}

${ }^{\text {a Saturated fatty acids }}$

${ }^{\mathrm{b}}$ Monounsaturated fatty acids

cPolyunsaturated fatty acids
Histopathological examination of hepatic tissue

Livers excised from a control group showed a normal architecture of hepatocyte lobules with normal central and portal areas and normal hepatocytes (Fig. 7a). The liver samples from $\mathrm{CCl}_{4}$-intoxicated rats showed severe feathery degeneration and necrosis of hepatocytes (Fig. 7b). The portal area showed severe infiltration by lymphocytes and dilation of the central vein (Fig. 7c). Rats treated with low dose of N. alba (100 mg/kg; P.O.) for 5 days showed slight improvement of the histopathological features of the liver compared with the $\mathrm{CCl}_{4}$-intoxicated group (Fig. 7d). However, a high dose of $N$. alba $(200 \mathrm{mg} / \mathrm{kg}$; P.O.) and silymarin showed marked advances in the liver features and disappearance of the feathery degeneration of hepatocytes (Fig. 7e and f, respectively).

\section{Immunohistochemical staining of caspase-3}

Liver excised from rats injected with $\mathrm{CCl}_{4}$ showed high caspase-3 expression ( $\mathrm{H}$ score $=60$; Fig. $8 \mathrm{~b}$ ) while, caspase3 was negatively stained in the control group $(\mathrm{H}$ score $=0$; Fig. 8a). Caspase-3 expression was decreased in $\mathrm{CCl}_{4}$-intoxicated rats treated with low dose of $N$. alba $(100 \mathrm{mg} / \mathrm{kg} ; \mathrm{H}$ score $=20$; Fig. 8c). $\mathrm{CCl}_{4}$-intoxicated rats received the high dose of $N$. alba as well as those received silymarin (Figs. 8d and e, respectively) showed negative staining for caspase-3 $(\mathrm{H}$ score $=0)$.

\section{Discussion}

The hyphenated HPLC-MS technique is an important method used for identifying complex mixtures, especially the phenolics in the crude extracts or the fraction found in the plant, either by using standard compounds (cochromatography) or by comparing mass spectra obtained with the literature (tentative identification) [22]. A chemical characteristic of the order Nymphaeals, which includes the family Nymphaeaceae, is the occurrence of significant amounts of gallic acid and ellagic acid [23]. Ellagitannins attracted considerable attention because of their vast structural diversity and biological activity, including antioxidant, antiviral and antitumor activity [24, 25].

N. alba flowers and rhizomes are known for their high phenolic content [9-11], while leaves have never been well studied before. In this study, $N$. alba AEE was demonstrated as a very rich source of phenolic compounds where, hydrolysable tannins were the main polyphenols identified (forty-two compounds) distinguished by their characteristic fragment ion spectra yielding losses of galloyl (m/z 152), gallate $(\mathrm{m} / \mathrm{z} 170)$ and esters of hexahydroxydiphenic acid (HHDP) residues $(\mathrm{m} / \mathrm{z} 302)$, while the common loss of $44 \mathrm{amu}$ indicates the presence of a free carboxylic group $(\mathrm{COOH})[26,27]$.

A total of twenty-six ellagitannins were tentatively identified. HHDP and a polyol and in some cases, gallic acid represent the majority of Nymphaea constituents. 
Table 4 Effect of N.alba AEE on $\mathrm{CCl}_{4}$-induced changes in the liver function parameters in rats. Rats were intoxicated with $\mathrm{CCl}_{4}(0.5 \mathrm{ml} / \mathrm{kg}$; I.P.) and treated with N. alba (100 and $200 \mathrm{mg} / \mathrm{kg}$; P.O.) and silymarin (100 mg/kg; P.O.) for 5 days. ALT, AST, total bilirubin, GGT and ALP were measured

\begin{tabular}{llllll}
\hline Parameter & Control & $\mathrm{CCl}_{4}$ & \multicolumn{2}{l}{ N.alba extract } & Silymarin \\
\cline { 5 - 6 } & & & Low Dose $(100 \mathrm{mg} / \mathrm{kg})$ & High Dose $(200 \mathrm{mg} / \mathrm{kg})$ & $(100 \mathrm{mg} / \mathrm{kg})$ \\
\hline ALT $(\mathrm{U} / \mathrm{L})^{1}$ & $32.6 \pm 3.1$ & $88.1 \pm 7.3^{\mathrm{a}}$ & $58.4 \pm 4^{\mathrm{b}}$ & $41.9 \pm 2.6^{\mathrm{b}}$ & $38.1 \pm 2.2^{\mathrm{b}}$ \\
AST $(\mathrm{U} / \mathrm{L})^{2}$ & $68.5 \pm 3.5$ & $139 \pm 8.3^{\mathrm{a}}$ & $105.9 \pm 4.1^{\mathrm{b}}$ & $82.1 \pm 6.1^{\mathrm{b}}$ & $72.5 \pm 4.7^{\mathrm{b}}$ \\
Total Bilirubin $(\mathrm{mg} / \mathrm{dl})$ & $0.2 \pm 0.02$ & $1.2 \pm 0.1^{\mathrm{a}}$ & $0.5 \pm 0.03^{\mathrm{b}}$ & $0.3 \pm 0.03^{\mathrm{b}}$ & $0.2 \pm 0.02^{\mathrm{b}}$ \\
GGT $(\mathrm{U} / \mathrm{L})^{3}$ & $7.7 \pm 0.6$ & $35.9 \pm 3.3^{\mathrm{a}}$ & $20.8 \pm 1.8^{\mathrm{b}}$ & $12.9 \pm 1.2^{\mathrm{b}}$ & $12 \pm 1.2^{\mathrm{b}}$ \\
ALP $(\mathrm{U} / \mathrm{L})^{4}$ & $278.5 \pm 19.1$ & $496.5 \pm 38.3^{\mathrm{a}}$ & $414.7 \pm 10.9^{\mathrm{b}}$ & $346.6 \pm 22.8^{\mathrm{b}}$ & $294.2 \pm 15.4^{\mathrm{b}}$
\end{tabular}

Data are presented as the mean $\pm \mathrm{SEM}, n=8$. ${ }^{\mathrm{a} S i g n i f i c a n t}$ difference from control group; $P<0.05$. ${ }^{\mathrm{b}}$ Significant difference from $\mathrm{CCl}{ }_{4}$ group; $P<0.05$

${ }^{1}$ Alanine aminotransferase

${ }^{2}$ Aspartate aminotransferase

${ }^{3}$ Gamma glutamyl transpeptidase

${ }^{4}$ Alkaline phosphatase

Peak 1 with a precursor ion at $m / z 481$ was identified as HHDP-glucose [28, 29]. The presence of HHDP was supported by the formation of $\mathrm{m} / z 301$ in the negative ionization and 303 in the positive.

Peak 31, shows $m / z$ at $633[\mathrm{M}-\mathrm{H}]$ and fragment ions at $\mathrm{m} / z 301$ [M-H-152-180], 589 [M-H-44], 481 [M-H152] was tentatively identified as a galloyl-HHDPglucose (corilagin) isomer, agreeing with Fischer et al., [30] and Barros et al. [31]. Peak 32 shows $m / z$ at 783 [M-H] and fragments at $\mathrm{m} / z 481$ [M-H-302] and 301 [M-H-302-180] was identified as pedunculagin (Bis HHDP hexoside), the release of one HHDP molecule yielded 481 (peak 1) [32]. Two compounds with $m / z 951$ were detected at different retention time (Peak 38 and 50) which significantly differ in their fragmentation pattern, indicating the presence of isomeric structures which is common with ellagitannins. They were tentatively identified as granatin $\mathrm{B}$ and geraniin respectively $[33,34]$.

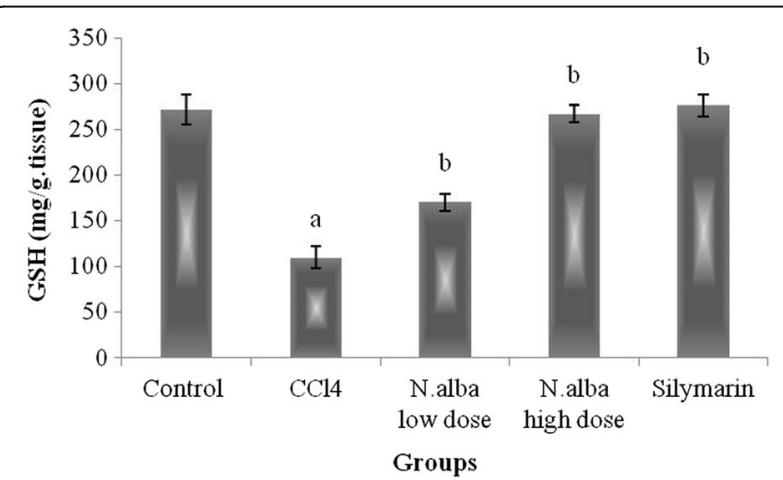

Fig. 1 The effect of $\mathrm{N}$. alba AEE on the liver content of GSH in $\mathrm{CCl}_{4}^{-}$ intoxicated rats. Rats were intoxicated with $\mathrm{CCl}_{4}(0.5 \mathrm{ml} / \mathrm{kg} ; \mathrm{I} . \mathrm{P}$.) and treated with N. alba (100 and $200 \mathrm{mg} / \mathrm{kg} ;$ P.O.) and silymarin (100 mg/ kg; P.O.) for 5 days. GSH was determined in the liver homogenate. Data

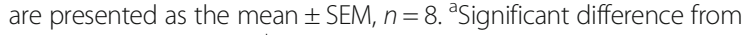

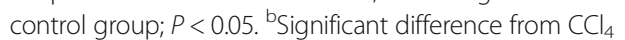
group; $P<0.05$
Three lagerstannins previously identified in Lagerstroemia speciosa were tentatively identified with the presence of gluconic acid. The common loss of $44 \mathrm{amu}$ indicates the presence of a free carboxylic group [35]. Peak 35 shows $m / z$ at $649[\mathrm{M}-\mathrm{H}]$ and fragments at $m / z 603$ [M$\mathrm{H}-44], 631$ [M-H-18], 469 [M-H-180], 451 [M-H-44-152] and 301, which was identified as lagerstannin $\mathrm{C}$ (galloyl HHDP-gluconic acid). Peak 9 presents $m / z$ at $799[\mathrm{M}-\mathrm{H}]$ and fragments at $m / z 755$ [M-H-44], 497 [M-H-302] and 301 [M-H-302-196] and identified as lagerstannin A (BisHHDP-gluconic acid). Peak 37 shows $m / z$ at $949[\mathrm{M}-\mathrm{H}]$ and fragments at $m / z 647$ [M-H-302], 905 [M-H-44], 629 [M-H-44-152], 477 [M-H-302-170], 301 [M-H-302-170176]. This peak was tentatively identified as Lagerstannin $B$ (flavogalloyl-HHDP-gluconic acid) [30, 35].

Analysis of peaks 11, 27, 30 and 47, yielded intense product ions resulting from the loss of the HHDP and/or galloyl moiety. These peaks were tentatively identified as

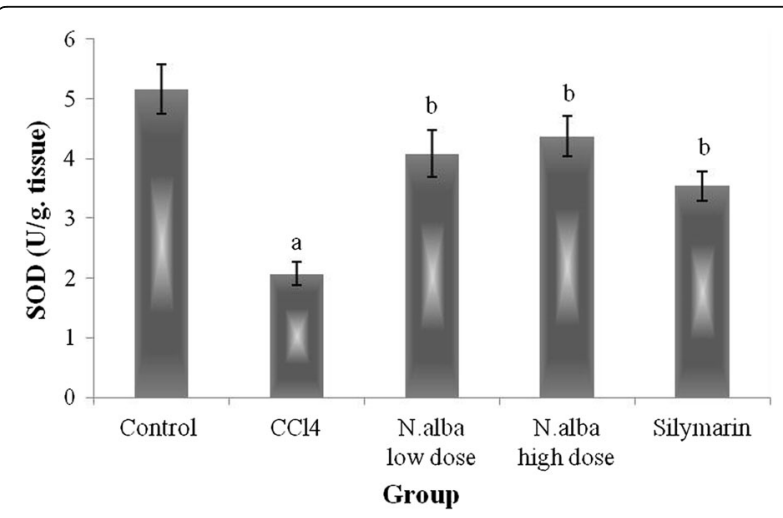

Fig. 2 The effect of $\mathrm{N}$. alba AEE on the liver SOD activity in $\mathrm{CCl}_{4}$ intoxicated rats. Rats were intoxicated with $\mathrm{CCl}_{4}(0.5 \mathrm{ml} / \mathrm{kg} ; \mathrm{I} . \mathrm{P}$.) and treated with N. alba (100 and $200 \mathrm{mg} / \mathrm{kg}$; P.O.) and silymarin (100 mg/ kg; P.O.) for 5 days. SOD was determined in the liver homogenate. Data are presented as the mean $\pm \mathrm{SEM}, n=8$. ${ }^{\mathrm{a}}$ Significant difference from control group; $P<0.05$. ${ }^{b}$ Significant difference from $\mathrm{CCl}_{4}$ group; $P<0.05$ 


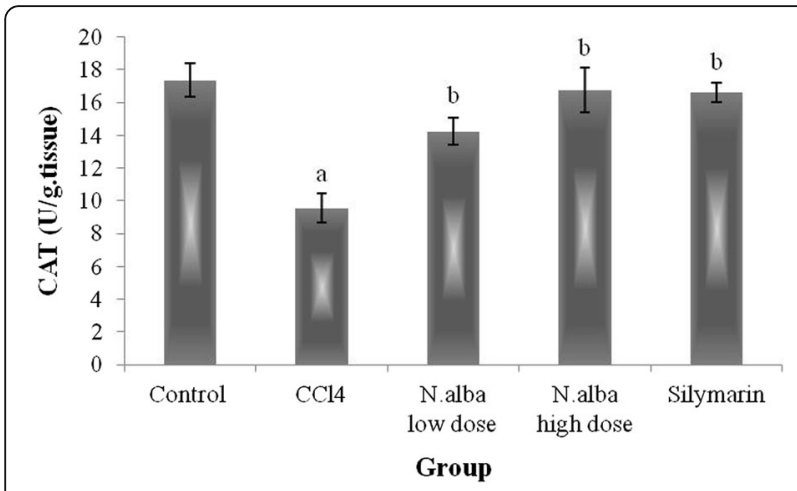

Fig. 3 The effect of $N$. alba AEE on the liver CAT activity in $\mathrm{CCl}_{4}{ }^{-}$ intoxicated rats. Rats were intoxicated with $\mathrm{CCl}_{4}(0.5 \mathrm{ml} / \mathrm{kg} ; \mathrm{IP}$.) and treated with N. alba (100 and $200 \mathrm{mg} / \mathrm{kg}$; P.O.) and silymarin (100 mg/ kg; P.O.) for 5 days. CAT was determined in the liver homogenate. Data are presented as the mean $\pm \mathrm{SEM}, n=8$. ${ }^{\mathrm{a}}$ Significant difference from control group; $P<0.05$. ' Significant difference from $\mathrm{CCl}_{4}$ group; $P<0.05$

phyllanthusiin U, B, C and chebulagic acid detected with $[\mathrm{M}-\mathrm{H}]$ at $m / z$ 924, 969, 925 and 953, respectively and previously identified in Phyllanthus urinaria [36, 37]. Peak 28 with a pseudomolecular ion $[\mathrm{M}-\mathrm{H}]$ at $m / z 933.06$ and fragment ions at $m / z$ 915, 631, 451 and 301 were in agreement with the fragmentation pattern attributed to castalagin [38]. The release of one HHDP or ellagic acid moiety (302 Da) from castalagin generated Peak 33 with an $[\mathrm{M}-\mathrm{H}]$ at $\mathrm{m} / \mathrm{z}$ 631, showing the typical ellagic acid fragments at $\mathrm{m} / \mathrm{z} 299$ and $\mathrm{m} / \mathrm{z} 271$ and tentatively identified as castalin $[28,30]$.

The free ellagic acid was confirmed by its MS data and MS/MS fragmentation (peak 5), having $m / z$ at 301 [M-H] in the negative mode and fragment ions at $m / z 275,257$, 247, 229 and 185 [38]. Peaks 17, 48, 49 were tentatively identified as the glycosylated forms of ellagic acid with $[\mathrm{M}-\mathrm{H}]$ at $m / z 463,433$ and 447 , respectively, showing the

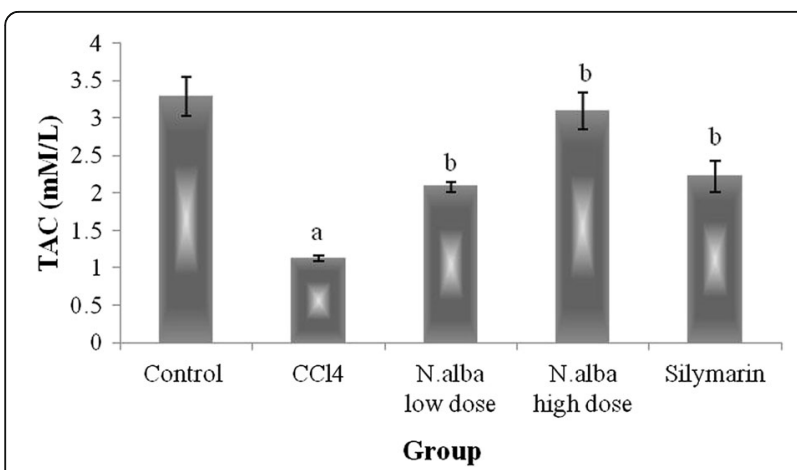

Fig. 4 The effect of $N$. alba AEE on the liver TAC in $\mathrm{CCl}_{4}$-intoxicated rats. Rats were intoxicated with $\mathrm{CCl}_{4}(0.5 \mathrm{ml} / \mathrm{kg}$; I.P.) and treated with N. alba (100 and $200 \mathrm{mg} / \mathrm{kg}$; P.O.) and silymarin (100 mg/kg; P.O.) for 5 days. TAC was determined in the liver homogenate. Data are presented as the mean \pm SEM, $n=8$. ${ }^{\text {a }}$ Significant difference from

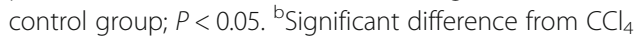
group; $P<0.05$

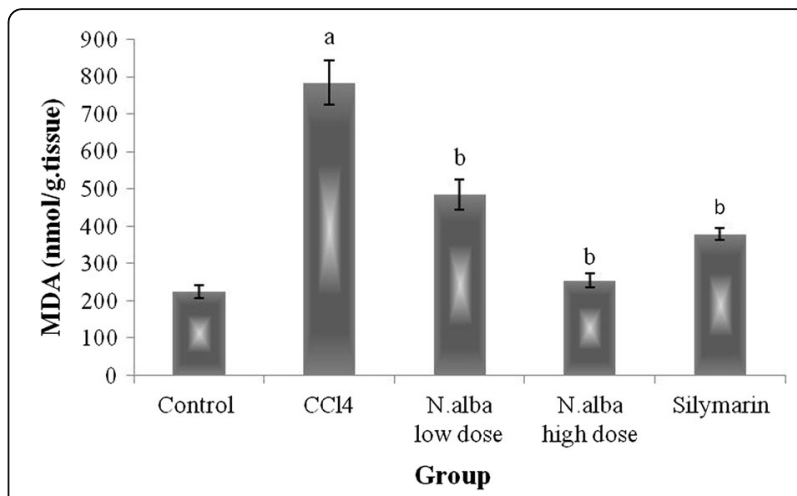

Fig. 5 The effect of $N$. alba AEE on the liver content of $\mathrm{MDA}$ in $\mathrm{CCl}_{4}$ intoxicated rats. Rats were intoxicated with $\mathrm{CCl}_{4}(0.5 \mathrm{ml} / \mathrm{kg} ; \mathrm{I} . \mathrm{P}$.) and treated with N. alba (100 and $200 \mathrm{mg} / \mathrm{kg} ;$ P.O.) and silymarin (100 mg/kg; P.O.) for 5 days. MDA was determined in the liver homogenate. Data are presented as the mean \pm SEM, $n=8$. a Significant difference from control group; $P<0.05$. ${ }^{\text {bS Significant }}$ difference from $\mathrm{CCl}_{4}$ group; $P<0.05$

characteristic fragments of ellagic acid at $m / z 301$ and 275 in addition to the characteristic losses of a hexosyl, pentosyl and rhamnosyl residue, so, identified as ellagic acid hexoside, pentoside and rhamnoside respectively [30]. Peak 42 presents $m / z$ at $469[\mathrm{M}-\mathrm{H}]$ and a fragment at $m / z$ 425, was tentatively identified as valoneic acid dilactone, a compound that often occurs in plants containing ellagitannins [39]. While peak 12 represented a dimer of valoneic acid dilactone with $[\mathrm{M}-\mathrm{H}]$ at $\mathrm{m} / z 939$ and main fragments at 469 and 425 .

Gallic acid and its derivatives were also tentatively identified where gallic acid appeared at peak $\mathbf{5 3}$ while peak 39 was tentatively identified as dehydrated tergallic acid with a pseudomolecular ion $[\mathrm{M}-\mathrm{H}]$ at $m / z 613$ and

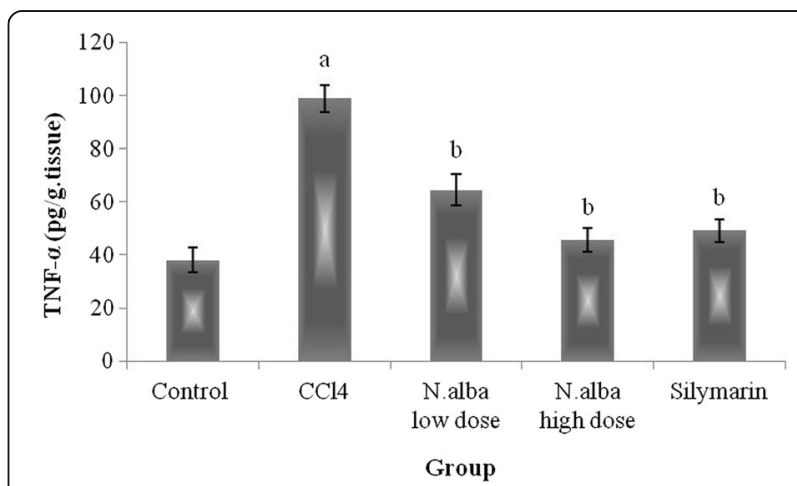

Fig. 6 The effect of $N$. alba AEE on the liver content of TNF-a in $\mathrm{CCl}_{4}$-intoxicated rats. Rats were intoxicated with $\mathrm{CCl}_{4}(0.5 \mathrm{ml} / \mathrm{kg}$; I.P.) and treated with N. alba (100 and $200 \mathrm{mg} / \mathrm{kg}$; P.O.) and silymarin (100 mg/kg; P.O.) for 5 days. TNF-a was determined in the liver homogenate. Data are presented as the mean \pm SEM, $n=8$. aSignificant difference from control group; $P<0.05$. ' ${ }^{\text {Significant }}$ difference from $\mathrm{CCl}_{4}$ group; $P<0.05$ 


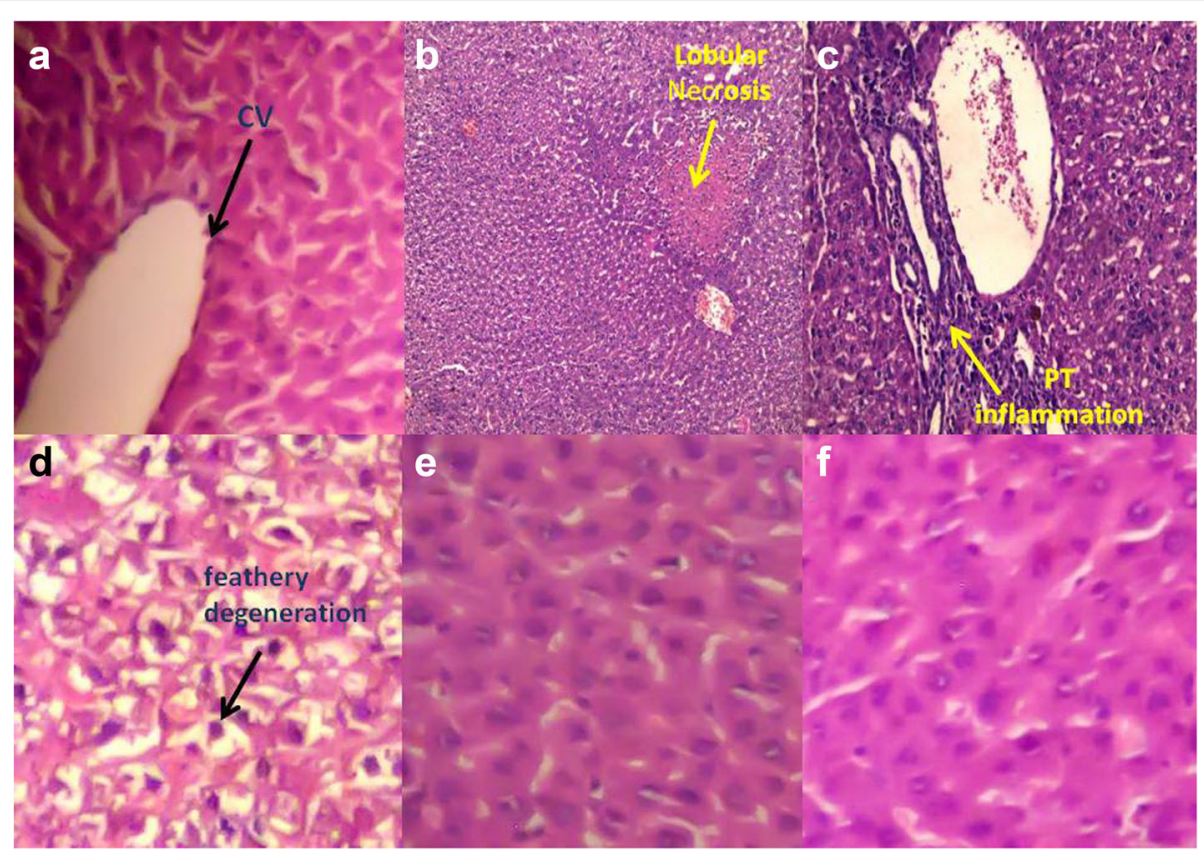

Fig. 7 Representative photomicrographs of histopathological examination of the liver. a Liver of control rats (b and $\mathbf{c}$ ) Liver of rats intoxicated with $\mathrm{CCl}_{4}(0.5 \mathrm{ml} / \mathrm{kg} ;$ P.O.) showing severe feathery degeneration of hepatocytes and lobular necrosis (B) and portal lymphocytic infiltration (c). $\mathbf{d}$ Liver of rats intoxicated with $\mathrm{CCl}_{4}$ and treated with $\mathrm{N}$. alba $(100 \mathrm{mg} / \mathrm{kg} ;$ P.O.) showing slight improvement of feathery degeneration of hepatocytes. e Liver of rats intoxicated with $\mathrm{CCl}_{4}$ and treated with N. alba $(200 \mathrm{mg} / \mathrm{kg}$; P.O.) showed marked improvement of the histopathological features. $\mathbf{f}$ Liver of rats intoxicated with $\mathrm{CCl}_{4}$ and treated with silymarin (100 mg/kg; P.O.)

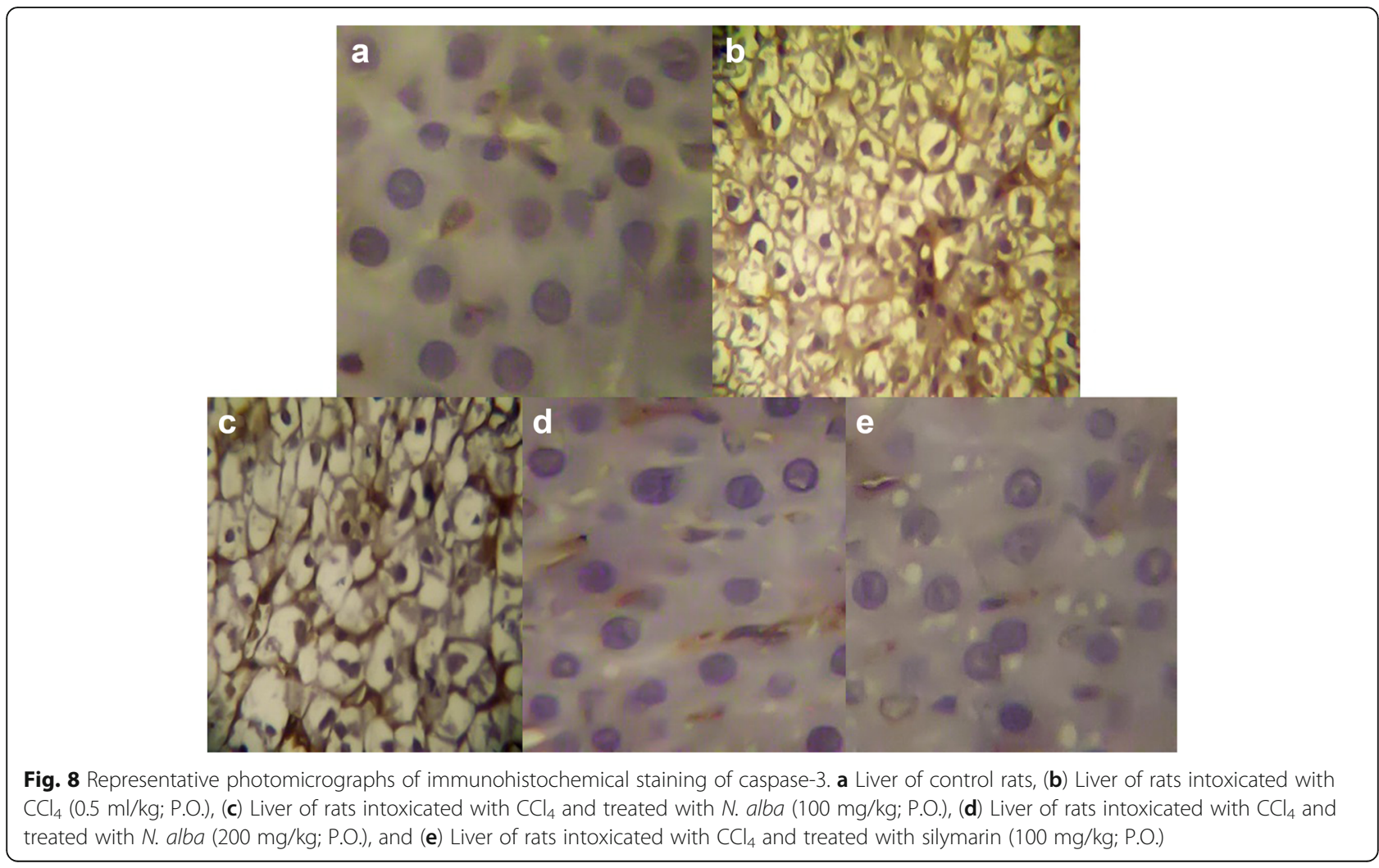


fragment ions at $m / z 569$ [M-H-44], 461 [M-H-152] and 299 [M-H-152-162] [29, 30].

Flavonoids have also been detected where Peak 8 shows $m / z$ at $505[\mathrm{M}-\mathrm{H}]$ and daughter ion at $m / z 301$ [M-acetyl hexoside], was tentatively identified as quercetin 3-O-acetyl hexoside that was previously identified in the Nymphaea species [40]. Peak 31 has an [M-H] ion at $m / z 289$ and base peak at $m / z 245$ [M-H-44] was tentatively identified as catechin or epicatechin by Pérez-Magariño et al., [41].

Beside the phenolic content $N$. alba extract appeared also as rich source of fatty acid. Essential fatty acids (EFAs) such as linolenic, linoleic and oleic acids help to raise HDL cholesterol, supporting cardiovascular, reproductive and immune systems. $N$. alba extract contains several essential fatty acids as linoleic (16.78\%) and linolenic acid (24.45\%), and, therefore, has a potential nutritional value in agreement with Eromosele and Eromosele, [42]. In addition, $N$. alba provided a rich source of $\beta$-sitosterol (5\%), which is reported to reverse the impairment of the glutathione/oxidized glutathione ratio induced by phorbol esters in macrophage cultures with the increase in manganese superoxide dismutase and glutathione peroxidase activities and the decrease in catalase activity [43].

Oxidative stress plays a crucial role in the development of the aging process and some chronic diseases [21]. The antioxidant potential of medicinal plants is attributed to the redox properties of the phenolic compounds and there are several reports that correlate the total phenolic content to the antioxidant activity [44-46]. N. alba was shown as a potent radical scavenger with low $\mathrm{IC}_{50}(5.2 \pm 0.3 \mu \mathrm{g} / \mathrm{mL})$ compared with ascorbic acid. This high radical scavenging activity suggests the ability of $N$. alba to reduce oxidative stress.

In this study, the hepatoprotective effect of $N$. alba AEE against $\mathrm{CCl}_{4}$-induced hepatotoxicity was demonstrated for the first time in a dose-dependent manner. This protection was reflected biochemically by the significant improvement in serum levels of ALT, AST, ALP and GGT, indicating the ability of $N$. alba AEE to protect hepatocytes against the deleterious effects of $\mathrm{CCl}_{4}$. Furthermore, the significant decrease in the serum level of bilirubin indicated that bilirubin was taken up into the liver as a function of a healthy hepatocyte. The hepatoprotective effect of the extract against $\mathrm{CCl}_{4}$-intoxication was further supported by histopathological examinations which showed considerable improvement of the histopathological features of the liver with $N$. alba treatment.

Silymarin is a unique flavonoid complex that has been reported to possess strong hepatoprotective properties and commonly used in experiments as a reference hepatoprotective substance [47]. Silymarin has a broad array of in vitro and in vivo activities such as anti-inflammatory, antiapoptotic and antioxidant [48]. Our results showed that silymarin protects against $\mathrm{CCl}_{4}$-induced hepatotoxicity as reflected by the significant improvement in the liver enzymes and bilirubin as well as enhancement of the histopathological features of the liver which was in agreement to previous studies [46, 47]. The protective effect of a high dose of $N$. alba $(200 \mathrm{mg} / \mathrm{kg})$ against hepatotoxicity is comparable with the effect observed with silymarin $(100 \mathrm{mg} / \mathrm{kg})$ which indicates a strong hepatoprotective property of the high dose of N. alba.

Caspase-3 is a protein that plays a vital role in apoptosis [49]. In the present study caspase-3 was extensively expressed in the liver excised from $\mathrm{CCl}_{4}$-intoxicated rats denoting the correlation between $\mathrm{CCl}_{4}$ induced hepatotoxicity and the high level of apoptosis of the hepatocytes as previously reported [50]. $N$. alba decreased the level of caspase- 3 expression while the effect of the high dose of $N$. alba is similar to that of silymarin as both drugs showed negative staining for caspase-3. Consequently, the protective effect of $N$. alba extract against $\mathrm{CCl}_{4}$ is mediated, in part, by inhibition of apoptosis through caspase- 3 dependant pathway.

Oxidative stress has been shown to play a pivotal role in liver injury induced by $\mathrm{CCl}_{4}[51,52]$. Our results showed an obvious disturbance in oxidant-antioxidant balance of the liver subjected to $\mathrm{CCl}_{4}$ where injection of $\mathrm{CCl}_{4}$ increased the degree of lipid peroxidation as indicated by the significant increase in MDA level in the liver homogenate. Both non-enzymatic and enzymatic antioxidant defence mechanisms were deteriorated in $\mathrm{CCl}_{4}$-injected group. The oxidant-antioxidant status of the liver excised from $\mathrm{CCl}_{4}$-intoxicated rats was significantly improved by treatment with $N$. alba in a dosedependent manner. These findings imply a profound in vivo antioxidant effect of $N$. alba. These results are consistent with the studies documented by Khan and Sultana, [12, 13], who reported that N. alba extract suppresses chemically-induced oxidative stress and kidney damage in Wistar rats.

The strong antioxidant activity of silymarin has been documented previously in several studies [47, 48]. In the present study the antioxidant activity of the high dose of $N$. $a l b a$ is comparable to the antioxidant activity of silymarin.

TNF- $\alpha$ is an important inflammatory mediator that has been shown to be involved in diverse pathological processes and in our study, TNF- $\alpha$ is elevated significantly in the $\mathrm{CCl}_{4^{-}}$ intoxicated group, which was previously reported [51, 52]. Treatment with $N$. alba resulted in a significant decrease in the hepatic content of TNF- $\alpha$, which is comparable, in its high dose, with silymarin. This result indicates a profound anti-inflammatory effect of $N$. alba which was in agreement with that reported in models of acetic acid-induced vascular permeability and cotton pellet-induced granuloma. In both models, $N$. alba exhibited an anti-inflammatory effect in a dose-dependent manner, which can be comparable with that of diclofenac sodium [6]. 


\section{Conclusion}

The results highlight the high phenolic content of $N$. alba leaves, denoting the predominance of hydrolysable tannins, mainly ellagitannins, in addition to the flavonoid content of major antioxidant activity. $N$. alba also appeared as a rich source of essential fatty acid with high nutritional value. Administration of $N$. alba extract remarkably protected against $\mathrm{CCl}_{4}$-induced hepatotoxicity to an extent comparable with silymarin. The suppression of oxidative stress and the inhibition of a crucial pro-inflammatory mediator such as TNF- $\alpha$ might be the possible mechanisms for the hepatoprotective activity of $N$. alba that help in restoration of the physiological and histological features of the liver. This preclinical study provides convincing evidence that $N$. alba extract can control inflammatory and oxidative stressrelated liver diseases.

\begin{abstract}
Abbreviations
A: Absorbance; AAE: Aqueous ethanolic extract; ALP: Alkaline phosphatase; ALT: Alanine aminotransferase; AST: Aspartate aminotransferase; CAT: Catalase; DPPH: 1, 1-Diphenyl-2-picrylhydrazyl; EFAs: Essential fatty acids; FAME: Fatty acid methyl ester; GGT: Gamma glutamyl transpeptidase; GLC: Gas Liquid Chromatography; GSH: Reduced glutathione; HR-ESI-MS/MS: High-resolution electrospray ionisation mass spectrometry; MDA: Malondialdehyde; MUFA: Monounsaturated fatty acids; PUFA: Polyunsaturated fatty acids; SFA: Saturated fatty acids; SOD: Superoxide dismutase; TAC: Total antioxidant capacity; TNF-a: Tumour necrosis factor; USM: Unsaponifiable matter
\end{abstract}

\section{Acknowledgments}

The authors are thankful to Dr. Sheren Youns, Department of Pathology, Faculty of Medicine, Menofyia University, Egypt, for her help in the histopathological part of the study.

\section{Funding}

This research is not supported by any funding agency.

\section{Availability of data and materials}

The data and materials of this article are included within the article.

\section{Authors' contributions}

All authors conceived and designed the experiments. RO Bakr helped in plant extraction, interpretation of HR-ESI-MS/MS, GLC analysis, and DPPH assay. MM El-Naa, conducted animal experiments for hepatoprotective, anti-oxidant and anti-inflammatory activities and interpreted data. SS Zaghloul, helped in designing the experiment, revising the manuscript. MM Omar helped in plant extraction, designing and conducting the animal experiment. All authors read and approved the final manuscript.

\section{Competing interests}

The authors declare there are no competing interests.

\section{Consent for publication}

Not applicable.

\section{Ethics approval and consent to participate}

Animal care and handling was performed in conformance with approved protocols of ethics committee of the MSA University (Reference number EC 10 PG 10/2011) and Egyptian Community guidelines for animal care.

\section{Author details}

${ }^{1}$ Pharmacognosy Department, Faculty of Pharmacy, October University for Modern Sciences and Arts (MSA), Giza, Egypt. Pharmacology Department, Faculty of Pharmacy, October University for Modern Sciences and Arts (MSA), Giza, Egypt. ${ }^{3}$ Pharmaceutics Department, Faculty of Pharmacy, October University for Modern Sciences and Arts (MSA), Giza, Egypt. ${ }^{4}$ Axe of
Regenerative Medicine, Faculty of Medicine, Universite Laval, Quebec City, Canada.

Received: 12 October 2016 Accepted: 5 January 2017

Published online: 17 January 2017

\section{References}

1. Weber LW, Boll M, Stampfl A. Hepatotoxicity and mechanism of action of haloalkanes: carbon tetrachloride as a toxicological model. Crit Rev Toxicol. 2003;33(2):105-36. doi:10.1080/713611034

2. Liu C, Tao Q, Sun M, Wu JZ, Yang W, Jian P, Peng J, Hu Y, Liu C, Liu P. Kupffer cells are associated with apoptosis, inflammation and fibrotic effects in hepatic fibrosis in rats. Lab Invest. 2010;90(12):1805-16.

3. Cesaratto L, Vascotto C, Calligaris S, Tell G. The importance of redox state in liver damage. Ann Hepatol. 2004;3(3):86-92.

4. Basu S. Carbon tetrachloride-induced lipid peroxidation: eicosanoid formation and their regulation by antioxidant nutrients. Toxicology. 2003; 189(1-2):113-27. doi:10.1016/50300-483X(03)00157-4.

5. James AD. Duke's hand book of medicinal plants of the bible. USA: Taylor and Francis group; 2008. p. 302-5.

6. Jesurun J, Jagadeesh S, Ganesan S, Rao V, Eerike M. Anti-inflammatory activity of ethanolic extract of Nymphaea alba flower in swiss albino mice. Int J Med Res Heal Sci. 2013;2(3):474-8. doi:10.5958/j.2319-5886.2.3.082.

7. Paharia AK, Pandurangan A. Evaluation of hepatoprotective activity of ethanolic extract of Nymphaea alba Linn flower in experimental rats. Int J Biomed Res. 2013:4(7):349-54.

8. Madhusudhanan N, Lakshmi T, Kumar G, Ramakrishanan, Konda V, Roy A, Geetha $\mathrm{R}$. Invitro antioxidant and free radical scavenging activity of aqueous and ethanolic flower extract of Nymphaea alba. Int J Drug Dev Res. 2011;3(3):252-8.

9. Jambor J, Skrzypczak L. Phenolic acids from the flowers of Nymphaea alba. Acta Soc Bot Pol. 1991;60(1-2):127-32. doi:10.5586/asbp.1991.011.

10. Jambor J, Skrzypczak L. Flavonoids from the flowers of Nymphaea alba $L$. Acta Soc Bot Pol. 1991:60(1-2):119-25. doi:10.5586/asbp.1991.010.

11. Bakr RO, Wasfi R, Swilam, Sallam IE. Characterization of the bioactive constituents of Nymphaea alba rhizomes and evaluation of anti-biofilm as well as antioxidant and cytotoxic properties. J Med Plants Res. 2016;10(26):390-401.

12. Khan N, Sultana S. Inhibition of potassium bromate-induced renal oxidative stress and hyperproliferative response by Nymphaea alba in Wistar rats. J Enzyme Inhib Med Chem. 2005;20(3):275-83. doi:10.1080/14756360400028119.

13. Khan N, Sultana S. Anticarcinogenic effect of Nymphaea alba against oxidative damage, hyperproliferative response and renal carcinogenesis in Wistar rats. Mol Cell Biochem. 2005;271(1-2):1-11. doi:10.1007/s11010-005-2258-2.

14. Thippeswamy BS, Mishra B, Veerapur VP, Gupta G. Anxiolytic activity of Nymphaea alba Linn. in mice as experimental models of anxiety. Indian J Pharmacol. 2011;43(1):50-5. doi:10.4103/0253-7613.75670.

15. Bhandarkar MR, Khan A. Antihepatotoxic effect of Nymphaea stellata willd. against carbon tetrachloride-induced hepatic damage in albino rats. J Ethnopharmacol. 2004:91(1):61-4.

16. Hassaan Y, Handoussa H, El-Khatib AH, Linscheid MW, El Sayed N, Ayoub N. Evaluation of plant phenolic metabolites as a source of alzheimer's drug leads. Bio Med Res Int. 2014; Article ID 843263.

17. Vogel Al. A textbook of practical organic chemistry, 3rd ed. London: English language book society and Longman Group Ltd; 1939.

18. Shimada K, Fujikawa K, Yahara K, Nakamura T. Antioxidative properties of xanthan on the autoxidation of soybean oil in cyclodextrin emulsion. J Agric Food Chem. 1992;40(6):945-8. doi:10.1021/jf00018a005.

19. Oktay M, Gülçin I, Küfrevioğlu Öl. Determination of in vitro antioxidant activity of fennel (Foeniculum vulgare) seed extracts. LWT - Food Sci Technol. 2003:36(2):263-71. doi:10.1016/S0023-6438(02)00226-8.

20. El BK, Hashimoto Y, Muzandu K, Ikenaka Y, Ibrahim ZS, Kazusaka A, Fujita S, Ishizuka M. Protective effect of Pleurotus cornucopiae mushroom extract on carbon tetrachloride-induced hepatotoxicity. Japanese J Vet Res. 2009;57(2):109-18.

21. Mariani E, Polidori MC, Cherubini A, Mecocci P. Oxidative stress in brain aging, neurodegenerative and vascular diseases: An overview. J Chromatogr B. 2005;827(1):65-75. doi:10.1016/j.jchromb.2005.04.023.

22. Chua LS, Latiff NA, Lee SY, Lee CT, Sarmidi MR, Aziz RA. Flavonoids and phenolic acids from Labisia pumila (Kacip Fatimah). Food Chem. 2011;127(3): 1186-92. doi:10.1016/j.foodchem.2011.01.122.

23. Hegnauer R. Phytochemistry and plant taxonomy- an essay on the chemotaxonomy of higher plants. Phytochemistry. 1986;25(7):1519-35. doi: 10.1016/S0031-9422(00)81204-2. 
24. Okuda T, Yoshida T, Hatano T. Economic and medicinal plant research. London: Academic; 1991.

25. Okuda T, Yoshida T, Hatano T. Hydrolyzable tannins and related polyphenols. Fortschr Chem Org Naturst. 1995;66:101-17.

26. Hukkanen AT, Kokko HI, Buchala AJ, McDougall GJ, Stewart D, Kärenlampi $\mathrm{SO}$, Karjalainen RO. Benzothiadiazole induces the accumulation of phenolics and improves resistance to powdery mildew in strawberries. J Agric Food Chem. 2007;55(5):1862-70. doi:10.1021/jf063452p.

27. Mullen W, Yokota T, Lean ME, Crozier A. Analysis of ellagitannins and conjugates of ellagic acid and quercetin in raspberry fruits by LC-MSn. Phytochemistry. 2003;64(2):617-24. doi:10.1016/S0031-9422(03)00281-4.

28. Bai N, He K, Roller M, Zheng B, Chen X, Shao Z, Peng T, Zheng Q. Active compounds from Lagerstroemia speciosa, insulin-like glucose uptakestimulatory/inhibitory and adipocyte differentiation-inhibitory activities in 3 T3-L1 cells. J Agric Food Chem. 2008;56(24):11668-74. doi:10.1021/jf802152z.

29. Mena P, Calani L, Dall'Asta C, Galaverna G, García-Viguera C, Bruni R, Crozier A, Del Rio D. Rapid and comprehensive evaluation of (Poly)phenolic compounds in pomegranate (Punica granatum L.) Juice by UHPLC-MSn. Molecules. 2012;17(12):14821-40. doi:10.3390/molecules171214821.

30. Fischer UA, Carle R, Kammerer DR. Identification and quantification of phenolic compounds from pomegranate (Punica granatum L.) peel, mesocarp, aril and differently produced juices by HPLC-DAD-ESI/MSn. Food Chem. 2011;127(2):807-21. doi:10.1016/j.foodchem.2010.12.156.

31. Barros L, Dueñas M, Carvalho AM, Ferreira IC, Santos-Buelga C. Characterization of phenolic compounds in flowers of wild medicinal plants from Northeastern Portugal. Food Chem Toxicol. 2012;50(5):1576-82. doi:10. 1016/j.fct.2012.02.004.

32. Seeram NP, Lee R, Scheuller HS, Heber D. Identification of phenolic compounds in strawberries by liquid chromatography electrospray ionization mass spectroscopy. Food Chem. 2006;97(1):1-11. doi:10.1016/j. foodchem.2005.02.047

33. Sentandreu E, Cerdán-Calero M, Sendra JM. Phenolic profile characterization of pomegranate (Punica granatum) juice by high-performance liquid chromatography with diode array detection coupled to an electrospray ion trap mass analyzer. J Food Compos Anal. 2013;30(1):32-40. doi:10.1016/j.jfca.2013.01.003.

34. Choi SJ, Kim JK, Jang JM, Shin KH, Lim SS. Rapid identification of the aglucosidase inhibitory compounds from Thunberg's Geranium (Geranium thunbergii Sieb. et Zucc.). Food Sci Biotechnol. 2012;21(4):987-96.

35. Tanaka T, Tong H, Xu Y, Ishimaru K, Nonaka G, Nishioka I. Tannins and related compounds $C X V I I$. Isolation and characterization of three new ellagitannis, lagerstannin A, B and C, having a gluconic acid core, from Lagerstoemia speciosa (L.) PERS. Chem Pharm Bull. 1992;40(11):2975-80.

36. Huang ST, Wang CY, Yang RC, Wu HT, Yang SH, Cheng YC, Pang JH. Ellagic acid, the active compound of Phyllanthus urinaria, exerts in vivo antiangiogenic effect and inhibits MMP-2 activity. Evid Based Complement Alternat Med. 2011;2011:215035. doi:10.1093/ecam/nep207.

37. Wu HY, Lin TK, Kuo HM, Huang YL, Liou CW, Wang PW, Chuang JH, Huang ST. Phyllanthus urinaria induces apoptosis in human osteosarcoma 143B cells via activation of Fas/FasL- and mitochondria-mediated pathways. Evid Based Complement Alternat Med. 2012;2012:925824. doi:10.1155/2012/925824.

38. Piwowarski JP, Kiss AK. C-glucosidic ellagitannins from Lythri herba (European Pharmacopoeia): chromatographic profile and structure determination. Phytochem Anal. 2012;24(4):336-48. doi:10.1002/pca.2415.

39. Martucci MEP, De Vos RCH, Carollo CA, Gobbo-Neto L. Metabolomics as a potential chemotaxonomical tool: application in the genus Vernonia schreb. PLoS One. 2014;9, e93149. doi:10.1371/journal.pone.0093149.

40. Zhu M, Zheng X, Shu Q, Li H, Zhong P, Zhang H, Xu Y, Wang L, Wang L. Relationship between the composition of flavonoids and flower colors variation in tropical water lily (Nymphaea) cultivars. PLoS One. 2012;7(4), e34335. doi:10.1371/journal.pone.0034335.

41. Pérez-Magariño S, Revilla I, González-SanJosé ML, Beltrán S. Various applications of liquid chromatography-mass spectrometry to the analysis of phenolic compounds. J Chromatogr A. 1999;847(1-2):75-81. doi:10.1016/ S0021-9673(99)00255-1.

42. Eromosele CO, Eromosele IC. Fatty acid compositions of seed oils of Haematostaphis barteri and Ximenia americana. Bioresour Technol. 2002; 82(3):303-4. doi:10.1016/S0960-8524(01)00179-1.

43. Vivancos M, Moreno JJ. $\beta$-Sitosterol modulates antioxidant enzyme response in RAW 264.7 macrophages. Free Radic Biol Med. 2005:39(1):91-7. doi:10. 1016/j.freeradbiomed.2005.02.025.
44. Dziedzic SZ, Hudson BJF. Polyhydroxy chalcones and flavanones as antioxidants for edible oils. Food Chem. 1983;12(3):205-12. doi:10.1016/ 0308-8146(83)90007-9.

45. Rice-Evans C. Flavonoid antioxidants. Curr Med Chem. 2001;8(7):797-807.

46. López-Vélez M, Martínez-Martínez F, Del Valle-Ribes C. The study of phenolic compounds as natural antioxidants in wine. Crit Rev Food Sci Nutr. 2003; 43(3):233-44. doi:10.1080/10408690390826509.

47. Berger J, Kowdley KV. Is silymarin hepatoprotective in alcoholic liver disease? J Clin Gastroenterol. 2003;37(4):278-9.

48. Karimi G, Vahabzadeh M, Lari P, Rashedinia M, Moshiri M. "Silymarin", a promising pharmacological agent for treatment of diseases. Iran J Basic Med Sci. 2011;14(4):308-17.

49. Liang B, Guo XL, Jin J, Ma YC, Feng ZQ. Glycyrrhizic acid inhibits apoptosis and fibrosis in carbon-tetrachloride-induced rat liver injury. World J Gastroenterol. 2015;21(17):5271-80. doi:10.3748/wjg.v21.i17.5271.

50. Dai N, Zou Y, Zhu L, Wang HF, Dai MG. Antioxidant properties of proanthocyanidins attenuate carbon tetrachloride $(\mathrm{CCl}(4))$-induced steatosis and liver injury in rats via CYP2E1 regulation. J Med Food. 2014;17(6):663-9. doi:10.1089/jmf.2013.2834.

51. Roy S, Sannigrahi S, Majumdar S, Ghosh B, Sarkar B. Resveratrol regulates antioxidant status, inhibits cytokine expression and restricts apoptosis in carbon tetrachloride induced rat hepatic injury. Oxid Med Cell Longev. 2011;2011:703676. doi:10.1155/2011/703676.

52. Singh D, Arya PV, Sharma A, Dobhal MP, Gupta RS. Modulatory potential of aamyrin against hepatic oxidative stress through antioxidant status in wistar albino rats. J Ethnopharmacol. 2015;161:186-93. doi:10.1016/j.jep.2014.12.025.

\section{Submit your next manuscript to BioMed Central and we will help you at every step:}

- We accept pre-submission inquiries

- Our selector tool helps you to find the most relevant journal

- We provide round the clock customer support

- Convenient online submission

- Thorough peer review

- Inclusion in PubMed and all major indexing services

- Maximum visibility for your research

Submit your manuscript at www.biomedcentral.com/submit
C Biomed Central 